\title{
Perbedaan Manhaj Ulama dalam Fikih Perempuan Kontemporer dan Realitasnya di Indonesia
}

\begin{abstract}
Mayyadah
IAIN PALU

Jl. Diponegoro No. 20 Kota Palu Sulteng

e-mail:mayyadah@iainpalu.ac.id

\begin{tabular}{llll} 
Submit & $:$ 2 Juli 2021 & Diterima & $: 2$ Nopember 2021 \\
Revisi & $: 1$ Oktober 2021 & Terbit & $: 1$ Desember 2021 \\
\hline
\end{tabular}

Abstract: The complexity of the problems and the reality of women in the modern era requires moslem scholars to establish actual and realistic legal solutions. This paper based on the fact that women's fiqh thought are influenced by the characteristics of the clerics manhaj and their legal determining methods. Through the literature study method (library research) and the fiqh-usūl fiqh approach, this paper finds that there are three characters of the clerics manhaj in women's fiqh, namely al-tasyaddud or al-ifrāțī, al-tafrìt wa al-tahallul, and al-wasț wa al-i'tidal. As for determining contemporary women's figh law, the scholars use a method through a comprehensive analysis of legal texts, paying attention to maqāsid al-syarì'ah, consideration of social context, and consideration of women's psychological and social differences. Meanwhile in Indonesia, the reality of women's activities has developed into practical politics world, resulting in various responses to fiqh ideas. It can be concluded that the problems of contemporary women's figh are not free from differences of opinion among moslem scholars.
\end{abstract}

Keywords: women's figh, cleric manhaj, legal method, contextual figh, contemporary figh

Abstrak: Kompleksnya permasalahan dan realitas perempuan di era modern menuntut para ulama untuk menetapkan solusi hukum yang aktual dan realistis. Tulisan ini berangkat dari kenyataan bahwa produk fikih perempuan juga dipengaruhi oleh karakteristik manhaj dan metode ulama dalam menetapkan hukumnya. Melalui kajian studi literatur (riset kepustakaan) dan pendekatan fikih-ușūl fikih, tulisan ini menemukan bahwa ada tiga karakter manhaj ulama dalam fikih perempuan yaitu al-tasyaddud atau al-ifrāțī, al-tafrìt wa al-tahallul, serta al-wasț wa al-i'tidāl. Adapun dalam menetapkan hukum fikih perempuan kontemporer, para ulama menempuh metode melalui analisis komprehensif terhadap nas-nas hukum, atensi terhadap maqāșid al-syarīah, pertimbangan realitas sosial, dan pertimbangan terhadap perbedaan psikologis dan sosial perempuan. Di Indonesia, realitas aktivitas perempuan telah merambah ke dunia politik praktis sehingga menghasilkan respon pemikiran fikih yang beragam. Di sini terlihat bahwa problematika fikih perempuan kontemporer tidak sepi dari perbedaan pendapat ulama.

Kata kunci: fikih perempuan, manhaj ulama, metode hukum, fikih realitas, fikih kontemporer. 


\section{Pendahuluan}

Dalam menetapkan hukum-hukum berkenaan perempuan, para ulama tidak hanya merujuk pada teks-teks Al-Qur'an dan Hadis, tetapi juga mempertimbangkan perbedaan kondisi sosial budaya masyarakat. Produk ijtihad para ulama tentu berkiatan erat dengan warna atau kecondongan manhaj yang dianutnya. Pada ranah fikih perempuan komtemporer, ada ulama yang cenderung sangat tekstual, ketat, dan sangat berhati-hati dalam menetapkan hukum. Sebaliknya, ada pula yang memilih bersikap moderat dengan mempertimbangkan perubahan kondisi dan zaman.

Modernisasi dan globalisasi telah menciptakan realitas sosial yang jauh lebih kompleks bagi perempuan zaman sekarang. Perempuan bukan hanya tampil pada semua aspek pelayanan dan pekerjaan publik, tetapi juga berkiprah dalam dinamika politik praktis. Menjamurnya lembaga pendidikan dan pesatnya teknologi informasi juga memberikan peluang bagi perempuan untuk meningkatkan kualitas akademiknya. Di sisi lain, tak sedikit perempuan yang harus mengusahakan sendiri sumber ekonomi bagi keluarga dan berperan ganda sebagai ibu rumah tangga sekaligus pencari nafkah.

Potret realitas perempuan modern memunculkan berbagai problematika termasuk di antaranya munculnya diskriminasi, kriminalisasi dan eksploitasi perempuan. Naasnya, perlakuan buruk yang dialami perempuan seringkali terlahir dari hasil interpretasi yang tidak proporsional terhadap perintah agama. ${ }^{1}$ Untuk itu, hal tersebut perlu diluruskan karena pandangan keagamaan dan nilainilai ajaran hukum dalam Islam sangat menghormati eksistensi perempuan, adapun kekerasan yang terjadi lebih banyak dipicu oleh konflik sosial-ekonomi-politik masyarakat. ${ }^{2}$ Ajaran Islam secara ideal-normatif memberikan keadilan bagi perempuan dengan mengangkat derajatnya ke tempat yang terhormat, memberikan kebebasan akses menuntut ilmu, dan membuka kesempatan aktualisasi diri yang selama ini tidak ditemukan dalam sistem masyarakat jahiliyah. ${ }^{3}$ Kompleksnya permasalahan dan realitas perempuan di era modern menuntut para ulama untuk menetapkan solusi hukum aktual. Perubahan realitas perempuan khususnya di Indonesia, menuntut adanya pendekatan fikih perempuan kekinian sehingga perubahan realitas tidak lantas membuat perempuan keluar dari batasan norma agama, tetapi dapat mengantarkannya pada keselamatan dunia dan akhirat. ${ }^{4}$

Oleh karena itu, tulisan ini mengkaji bagaimana manhaj ulama dalam fikih perempuan baik dari segi karakteristik maupun dari segi metode penetapan hukumnya. Tulisan ini juga berupaya mengeksplorasi penerapan manhaj tersebut dalam fatwa-fatwa ulama dan memotret dinamika produk fikih perempuan kontemporer di Indonesia. Kajian ini menggunakan metode penelitian kepustakaan atau studi literatur, dengan pendekatan fikih dan ușūl fikih.

\section{Karakteristik Manhaj Ulama dalam Fikih Perempuan}

Menurut Musfir al-Qahthani, secara umum manhaj fatwa ulama terbagi ke dalam 3 kelompok: ${ }^{5}$ Pertama, manhaj al-tadyì dan al-tasydìd yang memiliki ciri-ciri fanatisme mazhab tertentu dan

1 Nasaruddin Umar, Ketika Fikih Membela Perempuan (Jakarta: Elex Media Komputindo, 2014), xiv.

2 Faqihuddin Abdul Qodir, "Pengantar" dalam Husein Muhammad, Fiqh Perempuan Refleksi Kiai atas Tafsir Wacana Agama dan Gender (Cet. I; Yogyakarta: IRCiSoD, 2019), 33.

3 M.A. Sahal Mahfudz, "Pengantar" dalam Husein Muhammad, Fiqh Perempuan Refleksi Kiai atas Tafsir Wacana Agama dan Gender, 7.

4 Tutik Hamidah, "Dialektika Teks dan Konteks dalam Metode Istinbāṭ Fikih Perempuan Kontemporer”, Ahkam, Vol. XIII No. 1 (2013), 136.

5 Musfir al-Qahtani, "Manhaj Istikhrāj al-Aḥkām al-Fiqhiyyah li al-Nawāzil al-Mu'āṣarah”, Juz 1, (Saudi Arabiyyah: Kulliyyah al-Syarīah wa Dirasāt Islāmiyyah Jāmi’ah Umm al-Qurā, 2000), 308. 
cenderung sangat tekstual dalam memahami nas. Kedua, manhaj al-mubālagah fi al-tasāhul yang berlebihan dalam menerapkan konsep maslahat sehingga tak jarang menerbitkan produk ijtihad bertentangan dengan nas. Ketiga, manhaj al-wasați al-mu'tadil yang diaplikasikan kelompok ulama yang bersifat moderat dalam mempertimbangkan sebuah hukum, tanpa mengabaikan ketetapan nas. Faridah Haid juga mengemukakan tiga corak dalam fatwa-fatwa fikih wanita dengan manhaj yang tidak berbeda dari apa yang diungkapkan oleh Musfir al-Qahthani. Tiga aliran tersebut adalah mazhab al-tasyaddud atau al-ifrāțī, mazhab al-tafrìt wa al-tahallul, serta mazhab al-wasț wa al-i'tidāl. ${ }^{6}$

Di antara karakteristik manhaj al-tasyaddud adalah adanya klaim ijtihad mereka dengan alasan bahwa seseorang tidak boleh bertaklid. Kelompok ini berpendapat bahwa taklid adalah bid'ah dalam agama dan bukan bagian dari manhaj salaf. Ciri lain kelompok ini adalah sangat kuat berpegang pada teks dan fanatik terhadap makna literal teks tanpa memahami kaidah-kaidah pemaknaan teks tersebut. Sebagai akibatnya, mereka mengabaikan dalil-dalil ijtihad yang disepakati ulama seperti pengakuan terhadap 'urf' atau tradisi masyarakat dan prinsip kemaslahatan. Ketidaktahuan mereka terhadap prinsip Maqāṣid juga menjadi faktor penyebab fanatisme mereka. Selain terhadap makna literal teks, mereka juga fanatik terhadap satu pendapat tanpa berupaya menampilkan alternatif pendapat atau mengakui kebenaran pendapat orang yang lain. ${ }^{7}$

Di antara contoh fatwa wanita bermanhaj tasyaddud ini adalah fatwa yang mengharamkan segala bentuk aktivitas perempuan di luar rumahnya sehingga menyebabkan kesempitan dalam kehidupan manusia. ${ }^{8}$ Beberapa ulama Arab Saudi misalnya bahkan memfatwakan keharaman mengemudi kendaraan bagi wanita. Menurut Syekh Salih bin Muhammad al-'Utsaimin, untuk menghindari fitnah dan mencegah mudarat yang sangat besar bagi wanita maka wanita sebisa mungkin tidak mengemudi sendiri kendaraannya. Salah satu kemudaratan yang dikemukakan Syekh al-'Ustaimin adalah bahwa dengan mengemudi kendaraan, terbuka peluang bagi wanita untuk banyak keluar rumah, padahal tinggal di rumah lebih baik baginya. ${ }^{9}$ Sementara Syekh 'Abdullah bin Baz menyebutkan bahwa mengemudi kendaraan dapat menyebabkan wanita menyingkap wajahnya dan berkhalwat. ${ }^{10}$

Dari fatwa-fatwa hukum wanita yang dikemukakan oleh para ulama manhaj tasyaddud ini menunjukkan bahwa mereka memperluas aspek kehati-hatian atau kemudaratan dalam penetapan hukum seraya mempersempit pertimbangan terhadap kemaslahatan. Mereka melakukan generalisasi hukum untuk semua masa dan tempat, tanpa memperhatikan kondisi peminta fatwa dan pemberlakuan 'illat hukumnya. Kemudaratan yang disebutkan dalam hukum mengemudi tersebut, seperti melepas hijab, kebebasan wanita, berkhalwat dan sebagainya sesungguhnya terjadi hanya pada beberapa kondisi, bukan di semua kondisi. Terlebih lagi bahwa masalah mengemudi ini tidak ada landasan nas yang spesifik berbicara tentang pengharamananya secara mutlak. ${ }^{11}$

Kebalikan dari manhaj tasyaddud adalah manhaj al-tafriț wa al-tahallul. Ulama yang bermanhaj ini memiliki karakteristik berlebih-lebihan dalam‘amal bi al-mașlaḥ̄at sehingga seringkali mereka

\footnotetext{
6 Faridah Haid, “Al-Iftā' fĩ Qaḍāyā al-Mar'ah al-Mu'āṣarah baina al-Guluw wa al-I'tidāl”, al-Multaqā al-Daulī al-Rābi: Șunā'ah alFatwā Fī Ẓil al-Tahaddiyāt al-Mu'āṣarah, Vol.16 (13-14 Nopember 2019), 155. https://www.univ-eloued.dz/index.php/isi/85-cinstitute-science-islamique/tous-articles-ins-islamic/9858-1144701258 (10 Januari 2021).

7 Faridah Haid, “Al-Iftā' fĩ Qaḍāyā al-Mar'ah al-Mu'āșarah baina al-Guluw wa al-I’tidāl”, 155-156.

8 Usamah 'Umar Sulaiman al-Asyqar, Manhaj al-Iftà’’ inda Ibnu Qayyim al-Jauziyyah (Yordania: Dār al-Nafā’is, 2008$), 310$.

9 Muammad Salih al-'Ustaimin, "Hukum Mengemudi Kendaraan Bagi Wanita”, Situs Fatwa Online Șāid al-Fawā̉id, http://www. saaid.net/fatwa/f33.htm (10 Februari 2021).

10 'Abdullah bin Baz, "Hukum Mengemudi Kendaraan Bagi Wanita”, Situs Fatwa Online Syekh 'Abdullah bin Baz, https://binbaz.org. sa/articles/94/ حكم قيادة المرآ/A Februari 2021).

11 Faridah Haid, “Al-Iftā' 'īi Qaḍāyā al-Mar'ah al-Mu'āṣarah baina al-Guluw wa al-I’tidāl”, 160.
} 
mendahulukan maslahat meski pada kasus yang bertentangan dengan nas atau konsensus ulama (ijmak). Kelompok ini juga tak jarang mendahulukan hawa nafsu dalam berfatwa, dengan memberikan rukhșah tidak pada tempatnya dan menggunakan satu dalil, tanpa melihat dalil lainnya. ${ }^{12}$

Kelompok yang masuk dalam kategori ini di antaranya orang-orang yang terpengaruh paham Barat liberal, yang mengkritik hukum-hukum wanita dalam Islam tanpa melihat syarat-syarat hukumnya. Mereka berlebih-lebihan dalam melonggarkan hukum terhadap wanita, dengan alasan maqāṣid, kebebasan (emansipasi) wanita, dan demokrasi atau hak asasi manusia. ${ }^{13}$

Beberapa produk fatwa hukum wanita manhaj ini yaitu larangan laki-laki berpoligami, hak waris yang sama bagi perempuan, dan bolehnya wanita membuka aurat. Adapun kebolehan bagi wanita untuk tidak menutup auratnya yaitu dengan menolak hukum wajibnya jilbab. Di antaranya pendapat al-Asymawi yang menafsirkan jilbab dan khimār sebatas anjuran saja, bukan sebagai kewajiban yang hukumnya bersifat pasti. Sebagaimana yang dikutip oleh Quraish Shihab, bahwa al-Asymawi berpandangan jika jilbab hanyalah berlaku di masa lampau saat perbudakan masih ada, sehingga jilbab diwajibkan ketika itu sebagai identitas pembeda bagi wanita merdeka dengan hamba sahaya. ${ }^{14}$

Faridah Haid mengemukakan bahwa kebalikan dari manhaj tasyaddud yang sangat literal terhadap teks, klaim ijtihad manhaj al-tafrit justru dengan melabrak ketentuan teks yang sudah pasti hukumnya. Mereka mendewakan akal atau logika dengan berpandangan bahwa syariatlah yang harus mengikut kepada akal. Fatwa-fatwa yang dihasilkan nampak condong mengatasnamakan kemaslahatan dan meninggalkan aturan-aturan penerapan kemaslahatan yang telah ditetapkan para ulama mazhab fikih. ${ }^{15}$

Manhaj yang terakhir adalah al-wasațiyyah wa al-i'tidāl. Al-wasațiyyah adalah sebuah cara atau pendekatan yang dapat diterima baik oleh syariat maupun akal karena mendahulukan dalil-dalil yang tetap dari syariat, dengan memperhatikan perkembangan zaman. Kelompok manhaj ini adalah mereka yang senantiasa mempertimbangkan tradisi-tradisi masyarakat umum, yang dibangun di atas kemaslahatan yang tidak bertentangan dengan spirit nas. ${ }^{16}$ Mereka bukan hanya memperhatikan nas dari segi teks, tetapi juga konteksnya, tanpa bersikap keras atau terlalu longgar. Mereka juga tidak mengabaikan perbedaan pendapat para ulama dan tidak fanatik kepada satu pendapat tertentu. ${ }^{17}$

Menurut 'Abdul Majid Muhammad al-Sausah, wasațiyyah dalam berfatwa yaitu menetapkan fatwa berdasarkan prinsip al-taysir (memberikan kemudahan) sehingga mustaftī dapat dengan mudah menerapkan hukum syariat. Al-taysir bukanlah berarti menetapkan hukum baru atau menggugurkan hukum yang sudah ditetapkan oleh Allah, akan tetapi mendahulukan yang lebih mudah daripada lebih berhati-hati, terutama dalam kondisi umum manusia dan kondisi dimana diperbolehkan pemberian rukhșah. ${ }^{18}$

Senada dengan pernyataan tersebut, Yusuf al-Qaradawi juga menyebutkan bahwa salah satu prinsip manhaj wasațiyyah adalah yassirū wa lā tu'assirū (mudahkan, jangan mempersulit). Lebih lanjut ia mengatakan:

\footnotetext{
${ }^{12}$ Usāmah 'Umar Sulaimān al-Asyqar, Manhaj al-Iftā’ 'inda Ibnu Qayyim al-Jauziyyah, 319.

13 Faridah Haid, “Al-Iftā’ fī Qaḍāyā al-Mar'ah al-Mu'āṣarah baina al-Guluw wa al-I’tidāl”, 157.

14 Al-Asymawi dalam M. Quraish Shihab, Jilbab, Pakaian Wanita Muslimah, Pandangan Ulama Masa Lalu dan Cendekiawan Kontemporer (Cet.IV; Jakarta: Lentera Hati, 2012), 222.

15 Faridah Haid, “Al-Iftā' fī Qaḍāyā al-Mar'ah al-Mu'āṣarah baina al-Guluw wa al-I’tidāl”, 158.

16 Jamal 'Athiyyah dan Wahbah al-Zuhaili, Tajdìd al-Fiqh al-Islāmī (Beirut: Dār al-Fikr, 2000), 213.

17 Faridah Haid, “Al-Iftā' fĩ Qaḍāāā al-Mar'ah al-Mu'āṣarah baina al-Guluw wa al-I’tidāl”, 158.

18 'Abdul Majid Muhammad al-Sausah, Ḍawābiṭ al-Fatwā fī Qaḍāyā al-Mu'āṣarah, https://www.roudabooks.com/book/39440, 225 (23 Februari 2021).
} 


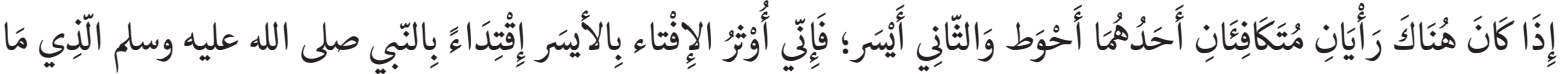

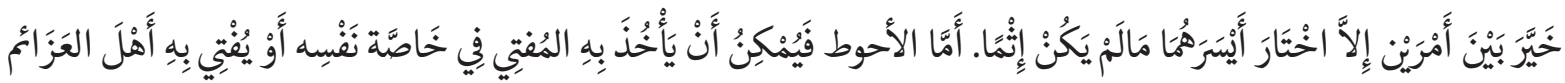

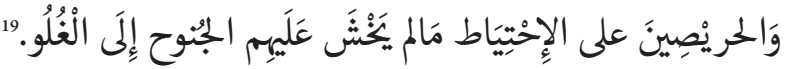

Jika terdapat dua pendapat yang setara (sama kuatnya), satunya lebih berhati-hati dan satunya lebih mudah, maka saya akan condong berfatwa yang lebih mudah karena mengikut kepada Rasululullah saw. yang beliau jika memilih dua hal, maka senantiasa memilih yang paling mudah selama itu bukan dosa. Adapun pendapat lebih berhati-hati, maka mufti boleh saja menggunakannya sebatas untuk pribadinya atau untuk orang-orang yang kuat ibadahnya dan ingin berhati-hati, selama ia tidak khawatir mereka itu jatuh pada ekstrimisme.

Sementara itu, Imam al-Syathibi menegaskan bahwa Syariat Islam pada hakikatnya senantiasa berjalan di atas koridor al-wasat al-a'dal. Hal tersebut tercermin pada semua aspek pembebanan hukum (taklif) di antaranya salat, puasa, haji, jihad, zakat dan lainnya. Oleh karena itu, jika terdapat dugaan bahwa hukum tersebut condong ke salah satu sisi (berat atau ringan), maka penetapan hukumnya dikembalikan kepada sisi al-wasaț al-a'dal. ${ }^{20}$

Di antara contoh hukum fikih wanita yang bermanhaj wasatiyyah yaitu sebagaimana yang difatwakan oleh sekelompok ulama kontemporer tentang kebolehan bagi wanita mengemudi kendaraan. Di antaranya ditetapkan oleh tim fatwa islamweb.net ${ }^{21}$ yang menyatakan bahwa boleh bagi wanita untuk mengemudi selama ada hajat atau untuk perjalanan yang 'urfi atau baik menurut tradisi masyarakat. Para ulama yang membolehkan beralasan bahwa jika wanita di zaman Nabi saw boleh menunggang kuda., maka tentu tidak mengapa membolehkannya untuk mengemudi kendaraan di zaman sekarang. ${ }^{22}$

\section{Metode Penetapan Hukum Fikih Perempuan Kontemporer}

Landasan utama penetapan hukum dalam masalah-masalah fikih adalah bersumber dari nas al-Qur'an dan Hadis. Dalam kaitannya dengan persoalan laki-laki dan perempuan, prinsip dasar nas menunjukkan pandangan yang egaliter dan universal. Teks-teks al-Qur'an dan hadis meski khităbnya menggunakan kata ganti mużakkar, namun perintah atau larangannya mencakup laki-laki dan perempuan kecuali ada nas lain yang menunjukkan kekhususan khițāb tersebut. ${ }^{23}$ Prinsip kesetaraan laki-laki dan perempuan juga ditunjukkan oleh firman Allah QS Al-Nahl/16: 97 berikut:

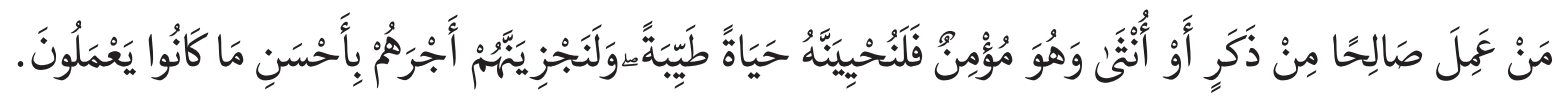

Barangsiapa mengerjakan kebajikan, baik laki-laki maupun perempuan dalam keadaan beriman, maka pasti akan Kami berikan kepadanya kehidupan yang baik dan akan Kami beri balasan dengan pahala yang lebih baik dari apa yang telah mereka kerjakan.

\footnotetext{
19 Yusuf al-Qaradawi, al-Fatwā Baina al-Indibāṭ wa al-Tasayyub (Cet. I; Kairo: Dār al-Ṣahwah, 1988), h. 114.

${ }^{20}$ Abū Isḥāq al-Syātibi, al-Muwāfaqāt fì Ușūl al-Syarī’ah, Juz 2 (Beirut: Dār al-Kutub al-‘Ilmiyyah, 2001), 124.

${ }^{21}$ Islamweb.net merupakan situs fatwa dwibahasa (Arab-Inggris) yang melayani konsultasi hukum secara online. Kantor situs ini berpusat di Qatar yang tim fatwanya terdiri dari beberapa pakar dalam fatwa, di bawah pimpinan Dr. Faqih "Abdullah. "Fatwa Center Islamweb.net", https://www.islamweb.net/en/fatawa/?tab=3 (2 Maret 2021).

${ }^{22}$ Faridah Haid, “Al-Iftā’ fī Qaḍāyā al-Mar'ah al-Mu'āșarah baina al-Guluw wa al-I’tidāl”, h. 161.

23 Imān al-Ṭuwairisy dan Muhā al-Māni', al-Khițāb al-Fiqhī al-Muta'alliq bi al-Mar'ah (Cet.I; London: Takween Centre, 2015), h. 38.
} 
Beberapa ulama kontemporer mengatakan bahwasanya perempuan-perempuan itu maśilāt atau sama kedudukannya dengan laki-laki dalam hal penciptaan dan kemuliaan, di luar apa yang dikecualikan oleh syariat seperti dalam masalah warisan. ${ }^{24}$ Pendapat mereka tersebut dilandaskan pada hadis Nabi saw yang berbunyi:

Kaum perempuan adalah saudara kandungnya kaum laki-laki.

Selain merujuk pada nas-nas kesetaraan perempuan dengan laki-laki, para ulama kontemporer juga memperhatikan teks-teks al-Qur'an dan hadis yang menjelaskan perbedaan antara laki-laki dan perempuan. Meski terdapat teks-teks nas menerangkan perbedaan tersebut, bukan berarti hal itu menimbulkan pembedaan yang menyebabkan penafsiran teks keagaaman bias gender. Perbedaan antara laki-laki dan perempuan dimaksudkan untuk mendukung kemaslahatan manusia yang saling melengkapi fungsi dan perannya dalam kehidupan sosial. ${ }^{26}$

Dalam wacana fikih perempuan kontemporer, beberapa isu sentral yang sering mencuat terutama dalam kompilasi fatwa ulama kontemporer yaitu masalah aurat atau hijab, khitan perempuan, kewarisan, persaksian, kepemimpinan perempuan dalam politik, pekerjaan di luar rumah, tren kecantikan, dan problematika relasi suami istri (hukum keluarga). Dari sini dapat disimpulkan bahwa wacana fikih perempuan kontemporer bukan hanya berkaitan dengan masalah-masalah perempuan modern yang tidak pernah terjadi sebelumnya, tetapi juga membahas tema-tema fikih perempuan klasik yang muncul dalam konteks yang baru dengan pendekatan modern.

Tak sedikit ulama kontemporer yang cenderung tekstual terhadap nas-nas hukum perempuan. Di antaranya, fatwa-fatwa perempuan yang diterbitkan oleh Syekh Ibnu Jibrin dan ulama lain yang tergabung dalam Majelis Fatwa Arab Saudi (al-Lajnah al-Dā’imah). Beberapa fatwa mereka yang dianggap merugikan perempuan sebagaimana yang dilontarkan oleh Khaled Abou Fadl seperti fatwa tentang larangan mengemudi mobil dan bepergian sendirian, larangan berfoto dan ziarah kubur. ${ }^{27}$ Fatwa-fatwa tersebut tentu banyak dipengaruhi oleh sistem sosial, kultur, dan doktrin mazhab yang mereka anut. Oleh karena itu, produk fikih perempuan yang ditetapkan oleh ulama kontemporer pun tidak serta-merta dapat diaplikasikan dalam semua tempat atau lingkungan masyarakat yang berbeda-beda.

Di sisi lain, beberapa ulama kontemporer bermanhaj moderat telah menetapkan hukum-hukum fikih perempuan dengan mempertimbangkan prinsip kemaslahatan. Metode ini sebagaimana yang mereka lakukan dalam cabang kajian fikih lainnya, di luar kajian fikih perempuan. Seorang fakih wajib memberikan alasan bahwa ijtihadnya itu akan memberikan atau mewujudkan kemaslahatan yang tidak bertentangan dengan dalil nas. Namun, untuk menentukan kemaslahatan bukanlah hal yang mudah sehingga dapat menyebabkan terjadinya ikhtiläf ulama dalam banyak masalah. ${ }^{28}$ Di

\footnotetext{
$\overline{24}$ Situs Fatwa Resmi Syekh bin Baz, https://binbaz.org/fatwas/20103/ما صحة - حديث-النساء- شقائق- الرجال. Diakses tanggal 27 April 2020. Lihat pula situs resmi Majelis Fatwa Yordania, http://www.aliftaa.jo/Question.aspx?QuestionId=2550\#. XMMXXLczbcc. Diakses tanggal 26 April 2020.

25 Muhammad bin 'Isa al-Tirmizi, Al-Jāmi' al-Șahịh (Sunan al-Tirmììi), Juz 1, Bab Ṭahārah, Nomor hadis 82 (Cet. II; t.tp.: Maktabah al-Bānī, 1978), 190.

26 Sa'ād Ibrāhim Șālih, Aḥkām ‘'ibādāt al-Mar'ah fì al-Syrì'ah al-Islāmiyyah (Cet. III; Kairo: Dar al-Diyā', 1993), h. 52

27 Iman Fadhilah, "Aplikasi Hermeneutika dalam Fiqh Perempuan (Studi Pemikiran Khaled Abou el Fadl tentang Fiqh Permepuan dalam Fatwa CRLO)", Iqtisad, Vol. 3 No. 1 (2016), 35.

28 Lembaga Fatwa Dār al-Iftā’ Mesir, Dawābiț al-Ikhtiyār al-Fiqh 'inda al-Nawāzil, terj. Adhi Maftuhin, Fiqih Nawazil Standar Berfiqih dalam Perbedaan Fatwa (Depok: Keira Publishing, 2017), 67.
} 
antara ulama yang tergolong moderat dalam menerbitkan fatwa-fatwa seputar fikih perempuan kontemporer yaitu Syekh Yusuf al-Qaradawi, Syekh Wahbah al-Zuhaili, dan Syekh 'Ali Jum'ah.

Secara garis besar, penetapan hukum fikih perempuan kontemporer bagi para ulama, terutama yang beraliran moderat tidak terlepas dari empat metode atau pendekatan yaitu: analisis komprehensif terhadap nas-nas hukum; atensi terhadap maqāșid al-syarỉah; pertimbangan realitas sosial dan kebutuhan masyarakat; dan yang terakhir adalah pertimbangan terhadap perbedaan psikologis dan sosial perempuan. ${ }^{29}$

\section{Analisis Komprehensif dan Proporsional terhadap Nașṣ-așṣ Hukum}

Dalam menghadirkan dalil-dalil yang menjadi landasan hukum fikih, maka seorang ulama hendaknya menganalisa dalil-dalil nas secara menyeluruh dan proporsional (syumūliyyah). Syumūliyyah tersebut dapat diaplikasikan pada satu kasus hukum tertentu atau pada kasus-kasus berbeda dalam tema yang sama (fikih tematik).

Penerapan metode ini pada kasus hukum tertentu contohnya sebagaimana yang dipraktikkan para ulama dalam memutuskan hukum bekerjanya seorang perempuan di luar rumah. Pada dasarnya, sebelum menetapkan hukumnya, seorang ulama harus menganalisis secara seimbang antara ayat al-Qur'an yang memerintahkan perempuan menetap di dalam rumahnya dengan ayat yang membolehkan perempuan keluar rumah. Mujtahid juga membandingkan teks-teks hadis yang berkaitan dengan hukum tersebut. Jika dalil-dalil dalam masalah ini sekilas bertentangan, maka dilakukan pendekatan al-jam'u di antara dalil-dalil tersebut..$^{30}$ Analisis komprehensif terhadap nas-nas tersebut akan menghasilkan suatu analisa hukum bahwa perempuan diperbolehkan keluar rumah dalam hal tertentu dengan syarat tertentu. Sebaliknya, jika syarat atau kondisi yang menyebabkan ia dibolehkan keluar rumah tersebut hilang, maka perempuan tidak diperkenankan bekerja di luar rumah. ${ }^{31}$

Analisis komprehensif dan proporsional dalam nas-nas hukum salah satunya telah diterapkan oleh Yusuf al-Qardawi dalam mayoritas fatwa fikih perempuannya. Al-Qardawi memfatwakan bahwa perempuan yang keluar rumah untuk melakukan kegiatan sosial, pendidikan, bekerja dan bermuamalah hukumnya boleh, selama wanita tersebut dapat memastikan terjaminnya keamanan dan perlindungan di tempat kerja. Selain itu, perempuan harus menjaga adab-adab islami seperti menutup aurat dengan sempurna, menjaga pandangan, tidak berdua-duaan dengan lawan jenisnya, dan memastikan bahwa kegiatan atau pekerjaan yang ia lakukan disebabkan oleh alasan mendesak dan dibenarkan oleh syariat..$^{32}$ Penetapan syarat-syarat khusus ini juga merupakan salah satu bentuk kehati-hatian terhadap nas-nas yang secara ketat mengatur interaksi wanita dengan lawan jenisnya.

\footnotetext{
${ }^{29}$ Imān al-Ṭuwairisy dan Muhā al-Māni', al-Khițāb al-Fiqhī al-Muta'alliq bi al-Mar'ah, 51.

30 Al-Jam'u wa al-Taufì merupakan salah satu dari beberapa pendekatan dalam menghadapi kontradiksi dalil. Menurut Jumhur, pendekatan lain yang dapat ditempuh yaitu (1) al-tarjịh dengan mengamalkan hukum dalil yang rājịh (lebih kuat); (2) alnāsikh wa al-mansūkh yaitu dengan menghapus hukum dalil yang ada sebelumnya dan menetapkan hukum dalil yang datang belakangan; (3) Al-Suqūt atau Tawaqquf yaitu tidak menguatkan dan tidak pula menghapus salah satu dari hukum dalil yang bertentangan. Lihat Muḥammad Ibrāhim Muḥammad al-Hafnāwī, al-Ta'āruḍ wa al-Tarjị̣̄ 'inda al-Ușūliyyīn wa Aśaruhumā fí alFiqh al-Islāmī (Cet. II; Mesir: Dār al-Wafā', 1987), 65-66.

31 Imān al-Ṭuwairisy dan Muhā al-Māni', al-Khițāb al-Fiqhī al-Muta'alliq bi al-Mar'ah, 53.

32 Yusuf al-Qaradawi, Fatāwā al-Mar'ah al-Muslimah, https://www.al-qaradawi.net/sites/default/files/pdf/da183-FATAWA-ELMAHRAAELMOSLIMA.pdf(27 April 2019), 41
} 
Adapun aplikasi metode ini pada kasus-kasus tematik di antaranya adalah masalah pembagian kewarisan. Sebelum memutuskan hukum waris seorang wanita, maka seorang ulama bukan hanya menganalisa dalil-dalil tentang hak waris perempuan, tetapi juga mengkaji dalil-dalil kewajiban nafkah bagi laki-laki. Pada kasus tema kewarisan, suatu hukum yang ditetapkan hendaklah memperhatikan keseimbangan antara hak dan kewajiban laki-laki dan perempuan, sehingga diperoleh kesimpulan bahwa laki-laki mendapatkan bagian warisan dua kali lipat dibanding perempuan karena kedudukannya sebagai seseorang yang wajib memberi nafkah dan mahar kepada perempuan. ${ }^{33}$

\section{Atensi terhadap Maqāṣid al-Syarīah}

Al-Syathibi dalam teori maqāṣidnya menyatakan bahwa tujuan Allah menetapkan Syariat di muka bumi adalah demi kemaslahatan umat manusia. Kemaslahatan tersebut terdiri dari kemaslahatan manusia di dunia dan kemaslahatan di akhirat secara bersama-sama. ${ }^{34}$ Pada praktiknya, para ulama menetapkan bahwa prinsip kemaslahatan harus senantiasa bergandengan dengan ketetapan nas. Hukum yang didasarkan pada kebutuhan atau kemaslahatan semata, tanpa berpegang pada ketetapan nas termasuk ke dalam golongan ifrātī (kebablasan), sementara penetapan hukum yang hanya berlandaskan pada tekstualitas nas tanpa memperhatikan kemaslahatan dan nilai-nilai maqāsid tergolong sebagai tafrịtī (gegabah). ${ }^{35}$

Melalui konsep, Maqāșid al-Syarī'ah Imam al-Syathibi menyebutkan tiga jenis kemaslahatan yang menjadi tujuan ditetapkannya sebuah hukum syariat yaitu: ${ }^{36}$

a. Durūriyyāt: yaitu kemaslahatan yang bersifat primer segala hal yang harus ada untuk mewujudkan kemaslahatan, sehingga jika tidak dilaksanakan maka akan terjadi mafsadah atau kerusakan. Aspek durūriyyāt berkaitan dengan 5 pemeliharaan utama pada kehidupan manusia yaitu pemeliharaan agama, jiwa, akal, keturunan dan harta. Contohnya, maslahat dalam larangan khamar adalah untuk memelihara akal manusia.

b. Hājiyyātt: kemaslahatan sekunder yaitu segala hal yang harus ada agar manusia tidak mengalami kesulitan (masyaqqah). Jika aspek ini ditiadakan, kemaslahatan umum tidak sampai terancam, namun menimbulkan kesulitan bagi hidup manusia. Contohnya, kebolehan untuk meringkas (qașar) salat ketika bepergian.

c. Tahsinniyyāt: kemaslahatan yang sifatnya sebagai aspek pelengkap atau estetika yaitu segala hal yang bernilai etis dan estetis yang jika aspek ini tidak terwujud maka tidak sampai mengancam kemaslahatan atau menimbulkan masyaqqah, hanya berakibat pada kekurangharmonisan dalam pandangan akal sehat, norma atau tradisi masyarakat. Contohnya adab berpakaian ketika hendak melaksanakan salat.

Prinsip dasar pada konsep maslahat al-Syathibi adalah bahwa maslahat harus sejalan dengan nas. Oleh karena itu jika terjadi pertentangan antara dalil 'aqlì dengan dalil naqlī, maka dalil naqlī harus didahulukan sehingga ia menjadi matbu' (diikuti), sedangkan akal menjadi tābi' (pengikut). Maslahat yang dipandang oleh nas mengandung suatu maslahat dan apa yang dilarang nas karena ia adalah mafsadat, maka itu pulalah maslahat dan mafsadat secara nalar karena Syariat tidaklah

\footnotetext{
33 Imān al-Ṭuwairisy dan Muhā al-Māni', al-Khițāb al-Fiqhī al-Muta'alliq bi al-Mar'ah, h. 54.

34 Abu Ishaq al-Syathibi, al-Muwāfaqāt fì Ușūl al-Syarī’ah, Juz 2 (al-Khubar: Dār Ibn 'Affān, 1997), 9.

35 Muhammad Shuhufi, Fatwa dan Dinamika Hukum Islam di Indonesia (Makassar: Alauddin University Press, 2011 ), 147.

36 Abu Ishaq al-Syathibi, al-Muwāfaqāt fì Ușūl al-Syarỉah, Juz 2, 7.
} 
diturunkan untuk menghancurkan sendi kehidupan manusia, sebaliknya ia justru bertujuan untuk menopang kebaikan manusia. ${ }^{37}$

Adapun dalam maslahat yang tidak dijelaskan secara terperinci oleh dalil-dalil nas yang khusus, maka nalar dapat menentukan ukuran maslahat tersebut selama tidak bertentangan dengan nas yang umum. Itulah sebabnya mengapa al-Syathibi sepakat dengan metode penetapan hukum mașlahah mursalah karena menurutnya, maslahat kategori ini tidak mutlak mursal karena masih ada dalil nas umum yang dapat dijadikan standar mengidentifikasi maslahat tersebut. ${ }^{38}$

Dalam mengaplikasikan metode mașlahah mursalah, al-Syathibi bukan berarti membebaskan terbentuknya inovasi-inovasi bentuk apapun atas dasar maslahat. Oleh sebab itu, ia lantas menyebutkan beberapa kaidah atau aturan yang harus diperhatikan oleh para ahli fatwa atau mujtahid..$^{39}$ Pertama, persesuaian dengan jalan maqāṣid tidaklah menafikan salah satu sumber dengan sumber lainnya atau dalil yang satu dengan dalil-dalil lainnya. Di sini, al-Syathibi menekankan keutuhan maslahat, artinya ia tidak mengandung muatan kontradiktif dengan dalil yang lain, terutama dalil nas. Kedua, dalam menganalisa maslahat, maka terdapat pandangan atau penilaian umum yang dapat disepakati oleh nalar dan dikonfirmasi kesesuaian maknanya dengan logika. Namun, kaidah ini tidak dapat diterapkan pada masalah-masalah ibadah, karena mayoritas ibadah tidak dapat dilogikakan maknanya secara terperinci. Contohnya dalam berwudu, kenapa yang dibasuh bukan kemaluan ketika seseorang buang angin, tetapi anggota badan tertentu? Di sini alSyathibi mengemukakan bahwa maslahat bersifat universal, dapat diterima secara umum oleh akal manusia, namun dalam hal ibadah, ia tidak membutuhkan konfirmasi akal.

Beberapa prinsip kemaslahatan dalam hukum fikih khususnya berkaitan dengan hukum wanita, telah dicontohkan oleh ayat-ayat al-Qur'an dalam menetapkan hukum talak, mahar, hingga kewarisan. Penerapan prinsip maslahat juga dapat ditelusuri melalui hadis-hadis Rasululullah saw dan fatwa para Sahabat dalam menyelesaikan masalah fikih wanita.

Atensi para ulama terhadap aspek maqāșid al-syarīah dalam fikih perempuan dapat dilihat contohnya dalam masalah perkawinan. Para fukaha klasik pada dasarnya tidak memberikan batasan usia perkawinan yang tegas bagi perempuan, namun para ulama modern sepakat bahwa jika perempuan berusia belia di bawah umur akan menikah maka perlu diperhatikan ada atau tidaknya kemaslahatan atau ada tidaknya kemudaratan dalam perkawinan tersebut, termasuk masalah yang berkaitan dengan kesehatan reproduksi perempuan..$^{40}$

\section{Pertimbangan Realitas Sosial}

Realitas sosial yang terdiri dari perbedaan kondisi adat dan tradisi dalam suatu masyarakat menjadi salah satu landasan pertimbangan utama dalam penetapan hukum. Fikih yang pada dasarnya bersifat dinamis meski mengacu pada teks-teks agama yang absolut tidak dapat dipisahkan dengan perubahan kondisi sosial masyarakat sehingga bisa saja ulama berbeda pendapat dalam satu masalah yang sama karena mempertimbangkan realitas yang berbeda pula.

\footnotetext{
37 Ahmad al-Raisuni, Nazriyyah al-Maqāșid 'inda al-Imām al-Syātibīi, Cet. IV (Herndon USA: The International Institute of Islamic Thought, 1995), 264.

38 Ahmad al-Raisuni, Naẓriyyah al-Maqāșid 'inda al-Imām al-Syāțibī, 291.

39 Abu Ishaq al-Syatibi, al-I'tișām (Mekkah: Maktabah al-Tauhīd, t.th.), 47-48.

40 Husein Muhammad, Fiqh Perempuan Refleksi Kiai atas Tafsir Wacana Agama dan Gender, 171.
} 
Pada dasarnya, perubahan fatwa dapat dilakukan jika terjadi perubahan zaman, kondisi, dan tradisi. Ibnu Qayyim al-Jauziyyah mengatakan:

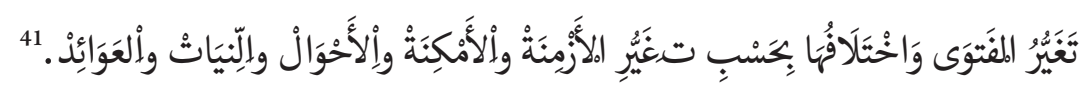

Perubahan fatwa dan perbedaannya tergantung pada perubahan zaman, tempat, kondisi, niat, dan kebiasaan.

Kaidah yang dilontarkan Ibnu Qayyim tersebut merupakan inovasi dari kaidah fikih yang menyebutkan bahwa perubahan hukum tidak mengingkari perubahan zaman yang diturunkan sebagai cabang dari kaidah fikih utama al-'ādah al-muhakkamah, artinya tradisi dapat menjadi landasan hukum. ${ }^{42}$ Kaidah perubahan fatwa tersebut merupakan kaidah yang dilandaskan pada konsep kemaslahatan manusia yang menjadi inti dari segala bentuk penerapan hukum Islam (fikih) sesuai dengan nilai taysir dan takhfif. Oleh karena itu, perubahan realitas perempuan modern juga dapat menjadi pertimbangan dalam menyesuaikan fatwa-fatwa seputar fikih perempuan, selama hal tersebut tidak bertentangan dengan nas yang qat ${ }^{\prime} i$.

Ulama lain yang juga menekankan pentingnya pemahaman terhadap realitas sosial adalah Imam Syihabuddin al-Qarafi. Ia mengatakan:

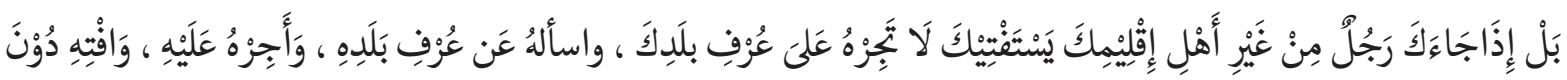

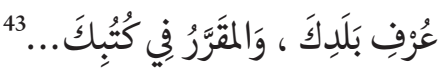

Jika datang kepadamu seseorang yang meminta fatwa dari negeri yang berbeda dari negerimu, maka janganlah kamu berfatwa sesuai tradisi negerimu. Dan tanyakanlah terlebih dahulu kepadanya tradisi negerinya dan berfatwalah sesuai dengan itu, bukan sesuai tradisimu atau apa yang ditetapkan dalam kitabmu (teks).

Hukum fikih perempuan yang mempertimbangkan realitas sosial di antaranya berkaitan dengan perubahan hak nafkah istri. Dalam masalah hak nafkah istri, para ulama berbeda pandangan dalam memasukkan batasan-batasan nafkah yang diwajibkan, namun hak istri yang wajib dinafkahi oleh suami di zaman modern tampaknya semakin kompleks sehingga menuntut penyelesaian hukum dari pada ulama. Salah satu ulama yang mengkritisi masalah ini adalah Wahbah al-Zuhaili.

Wahbah al-Zuhaili berpendapat jika fasilitas pengobatan dan servis kesehatan untuk istri sudah merupakan nafkah wajib yang dibebankan kepada suami. Al-Zuhaili melihat bahwa realitas kebutuhan keluarga modern akan tersedianya obat dan layanan kesehatan sudah masuk dalam tahap d̦arūrì. Apa yang ditetapkan oleh al-Zuhaili ini berbeda dengan mazhab ulama klasik yang belum mewajibkan jenis nafkah tersebut karena kebutuhan akan fasilitas kesehatan belum dianggap hal yang prioritas ketika itu. ${ }^{44}$

\footnotetext{
41 Ibnu Qayyim al-Jauziyyah, I'lām al-Muwaqqi'in 'an Rabb al-'Ālamīn, Juz 4 (Saudi 'Arabiyah: Dār al-Jauziyyah, 2002$), 337$.

42 'Abdul 'Azīz Muhammad 'Azzām, al-Qawā’id al-Fiqhiyyah (Kairo: Dār al-adīs, 2005), 198.

43 Syihābuddīn Al-Ṣanhājī al-Qarāfī, Kitāb al-Furūq Anwāru al-Burūq fī Anwā’u al-Burūq, Juz 1 (Cet I; Kairo: Dār al-Salām, 2001$), 314$.

44 Wahbah al-Zuhaili, Figh al-Islāmī wa Adillatuh, Juz 7 (Cet. II; Suriah: Dār al-Fikr, 1985), 794.
} 


\section{Pertimbangan terhadap Perbedaan Psikologis dan Sosial Perempuan}

Allah menciptakan laki-laki dan perempuan dengan keunikan dirinya masing-masing. Laki-laki dan perempuan setara namun berbeda. Perbedaan biologis laki-laki dan perempuan menyebabkan terjadinya perbedaan karakter kejiwaan (psikologis), sementara konstruksi masyarakat dan dinamika budaya berdampak pada perbedaan sosiologisnya. Perbedaan antara laki-laki dengan perempuan bukan berarti berujung pada diskiriminasi hukum.

Ajaran-ajaran agama tidak mesti berubah karena adanya perubahan sosial manusia, termasuk perubahan sosial perempuan. Namun karakter psikologis danfaktor sosiologisyang mempengaruhinya hendaklah dijadikan pertimbangan dalam menerbitkan produk ijtihad fikih perempuan.

Pemahaman akan fenomena personal dan sosial perempuan merupakan bagian dari idrāk alwāqi'. ${ }^{45}$ Saat mengidentifikasi sebuah masalah hukum, seorang pakar diharapkan dapat menemukan titik temu dari fenomena-fenomena realitas yang ada. Seorang mufti juga harus memperhatikan beberapa kondisi di antaranya mengetahui kasus yang dihadapkan kepadanya, mempelajari psikologi mustafti dan masyarakat lingkungannya agar dapat diketahui implikasi dari fatwa yang dikeluarkannya. ${ }^{46}$

Menurut Nasaruddin Umar, fikih banyak berbicara secara komprehensif tentang perempuan tiada lain karena ia merupakan interpetasi secara sosial budaya terhadap ajaran dasar Islam (syariah). Kitab-kitab fikih tradisional mayoritas bersumber dari literatur klasik yang umumnya disusun dari perspektif budaya masyarakat androsentris, di mana laki-laki menjadi ukuran segala sesuatu. Oleh karena itu, diperlukan pendekatan yang proporsional dalam melihat realitas sosial perempuan di masa sekarang. ${ }^{47}$

Hukum fikih yang mempertimbangkan dimensi sosiologis sekaligus psikologis wanita telah diaplikasikan oleh Rasulullah dalam masalah poligami. Kenyataannya, Rasulullah berpoligami dengan menikahi perempuan yang kebanyakan adalah janda, dengan usia yang tidak lagi muda. Poligami Rasulullah didasari pula pada latar atau situasi dakwah yang diembannya, di antara misinya adalah memberi pertolongan dan perlindungan kepada anak yatim yang kehilangan ayahnya, memperkokoh tali persahabatan dan mencegah perpecahan etnik, serta untuk menarik suatu kaum masuk Islam. ${ }^{48}$ Oleh sebab itu, praktik poligami yang dilakukan oleh Rasulullah saw. tidak lantas dapat dijadikan hujjah kebolehan berpoligami, tanpa meneladani nilai-nilai perkawinan yang dicontohkan Rasulullah. Penekanan terjaminnya keadilan nafkah di antara para istri menunjukkan bahwa Islam memperhatikan psikologis sekaligus sosial perempuan.

\section{Realitas Dinamika Fikih Perempuan Kontemporer di Indonesia}

Di Indonesia, kajian fikih perempuan kontemporer yang berupa kritik terhadap produk pemikiran fikih klasik yang bias gender banyak ditulis oleh ahli tafsir dan feminis muslim di antaranya, Hamka, M. Quraish Shihab, Husein Muhammad, Nasaruddin Umar, Muchith Muzadi,

\footnotetext{
${ }^{45}$ Idrāk al-Wāqi' meliputi pemahaman terhadap fenomena kebendaan, fenomena personal, fenomena peristiwa, dan fenomena pemikiran. Lihat Lembaga Fatwa Dar al-Iftā' Mesir, Ḍawābiț al-Ikhtiyār al-Fiqh 'inda al-Nawāzil, 21.

46 Muhammad Shuhufi, Fatwa dan Dinamika Hukum Islam di Indonesia, 100.

47 Nasaruddin Umar, "Pengantar" dalam Ketika Fikih Membela Perempuan, xvi.

48 Nasaruddin Umar, Ketika Fikih Membela Perempuan, 134.
} 
Masdar F. Mas'udi, Huzaemah T. Yanggo, Zaitunah Subhan, Musdah Mulia, dan Mansour Fakih. ${ }^{49}$ Adapun literatur-literatur khusus membahas masalah seputar fikih perempuan dan solusi hukumnya dapat ditemukan pada produk kompilasi fatwa lembaga keislaman di Indonesia seperti Majelis Ulama Indonesia, Muhammadiyah dan Nahdlatul Ulama. Berdasarkan penelusuran penulis, dari ketiga lembaga tersebut, hanya Muhammadiyah yang telah menerbitkan buku dan pedoman khusus tentang fikih perempuan,,$^{50}$ sementara dua lembaga lainnya masih menggabungkan dengan tema kajian fikih di luar fikih perempuan.

Untuk memotret dinamika fikih perempuan di Indonesia, maka perlu ditarik benang merah dengan pemikiran tokoh-tokoh reformis hukum Islamnya. Di antaranya Hasbi as-Ashiddiqi (1975) yang memunculkan gagasan perlunya dibentuk "Fikih Indonesia" agar tercipta dialektika teks dengan realitas tradisi Indonesia, juga Hazairin yang mengemukakan ide bahwa mazhab Syafi'iyyah harus dikembangkan dengan mengambil budaya lokal Indonesia. ${ }^{51}$

Mazhab Syafi'iyyah yang menjadi mazhab dominan di Indonesia perlu dikritisi lebih lanjut apakah masih relevan untuk diterapkan dalam masa sekarang. Karakter ijtihad Imam Syafi'i dalam memformulasikan fikih perempuannya dipengaruhi pada sistem patriarkis masyarakat Arab ketika itu dan domestikasi wilayah perempuan yang terjadi di masa hidupnya sehingga ia lebih menganjurkan perempuan untuk berdiam di dalam rumahnya. ${ }^{52}$

Sistem patriarkis yang membatasi wilayah peran perempuan masih ditemukan dalam sistem sosial masyarakat Indonesia khususnya di daerah pedesaan. Bahkan doktrin ini juga didapati di pesantren-pesantren. Karya fikih yang ditulis oleh Muh. Umar al Nawawy atau dikenal dengan Syaikh Nawawi Banten dlm kitab 'Uqūd Lujjain menjadi sasaran kritik bagi pengkaji masalah perempuan, padahal kita tersebut telah menjadi referensi hukum keluarga bagi kalangan pesantren di Indonesia. ${ }^{53}$ Dalam kitab tersebut seorang istri dideskripsikan sebagai manusia kelas dua dan tawanan bagi suaminya. Istri hanyalah objek pelengkap dalam rumah tangga. Pada tataran tersebut, fungsi dan peran perempuan terkesan sangat terbatas sehingga aktualisasi dirinya di luar rumah sangat tergantung pada suaminya..$^{54}$

Adapun contoh konkret dinamika fikih perempuan kontemporer di Indonesia dapat dilihat pada masalah politik wanita. Pada zaman sekarang, aktivitas perempuan Indonesia di luar rumahnya bahkan telah merambah ke dunia politik praktis. M. Quraish Shihab dalam bukunya Perempuan membandingkan tentang pendapat-pendapat ulama Indonesia dalam masalah politik perempuan. Menurutnya, ada beberapa ulama yang melarang perempuan menduduki jabatan presiden meskipun di satu sisi mereka membolehkan perempuan untuk ikut memilih dan dipilih dalam lembaga-lembaga pemerintahan. Dalih yang digunakan oleh ulama yang menentang kepemimpinan perempuan di antaranya ayat 34 surah an-Nisā' (al-rijālu qawwāmūna 'ala al-nisā'...), ayat 33 surah al-Aḥzāb (wa qarna

\footnotetext{
49 M. Noor Harisudin, “Pemikiran Feminis Muslim Indonesia tentang Fiqh Perempuan”, Al-Tahrir, Vol. 15 No. 2 (2015): 239.

50 Tafsir, "Pandangan Muhammadiyah Tentang Perempuan", https://tarjih.or.id/tajdid-muhammadiyah-dalam-persoalanperempuan/. (10 April 2019).

51 Tutik Hamidah, "Dialektika Teks dan Konteks dalam Metode Istinbāṭ Fikih Perempuan Kontemporer”, 142.

52 Zaenul Mahmudi, Sosiologi Fikih Perempuan: Formulasi Dialektis Fikih Perempuan dengan Kondisi Sosial dalam Pandangan Imam Syafi', 164.

53 Asni, "Pembaruan Hukum Islam di Indonesia, Telaah Epistemologis Kedudukan Perempuan dalam Hukum Keluarga", Disertasi (Makassar: PPs UIN Alauddin, 2012), 75.

${ }^{54}$ Husein Muhammad, Figh Perempuan Refleksi Kiai atas Tafsir Wacana Agama dan Gender, 261.
} 
fï buyūtikunna...), hadis-hadis yang berbicara tentang kelemahan perempuan dan hadis tentang tidak berjayanya suatu kaum jika dipimpin perempuan. ${ }^{55}$

Lebih lanjut Quraish menjelaskan bahwa teks-teks tersebut tidak dapat dipahami secara general. Terbukti bahwa pemimpin perempuan dalam sejarah tidak semuanya gagal, tetapi ada pula yang berhasil dan mampu memimpin rakyatnya sebagaimana keberhasilan Ratu Balqis yang tergambar dalam al-Qur'an. Di sisi lain, perlu diperhatikan bahwa prinsip utama dalam politik adalah musyawarah dan urusan musyawarah tidak terbatas hanya pada laki-laki saja. Harus diakui bahwa memang ulama-ulama klasik mayoritas tidak membolehkan perempuan menduduki jabatan sebagai kepala negara, namun menurut Quraish, hal ini disebabkan oleh situasi dan kondisi masa itu di mana perempuan sangat terbatas untuk terlibat di ruang publik. ${ }^{56}$

Lembaga Tarjih Muhammadiyah mengamini pendapat Quraish tersebut. Muhammadiyah melihat bahwa perkembangan realitas sosial di Indonesia membutuhkan keterlibatan perempuan termasuk dalam politik praktis untuk mencapai keterwakilan yang memadai. Muhammadiyah memandang bahwa keterlibatan dalam politik bukan dilihat dari jenis kelamin, tetapi tergantung pada kemampuan dan pengalaman seseorang. Meski membolehkan perempuan terlibat politik, namun Muhammadiyah memberikan beberapa catatan: pertama, perempuan yang akan terjun dalam politik harus melalui bimbingan politik agar perempuan sadar politik, kedua, harus ada kader-kader politik perempuan, dan ketiga adalah dalam kerjasama dengan lembaga lain, harus ditempatkan orang-orang yang memang memiliki kesanggupan menjadi fa'il. ${ }^{57}$

Berbeda dengan Muhammadiyah, hasil Bahtsul Masa'il Nahdlatul Ulama membolehkan perempuan menjadi anggota DPR/DPRD selama peran perempuan tersebut hanya sebagai pemberi saran kepada Ketua DPR/DPRD, bukan sebagai pemberi keputusan. Hukum kebolehan ini hanya berlaku selama perempuan tersebut memenuhi syarat-syarat yang ditetapkan yaitu ahli dalam masalah politik, menutup aurat, mendapat izin dari yang berhak memberi izin, aman dari fitnah, dan tidak menyebabkan timbulnya munkar menurut syara'. Jika syarat-syarat ini terpenuhi, maka haram hukumnya perempuan tersebut menjadi anggota parlemen. Batasan peran hanya sebagai pemberi saran, bukan pembuat keputusan terinspirasi dari pemahaman terhadap teks hadis tidak beruntung suatu kaum yang menyerahkan putusannya kepada perempuan..$^{58}$

\section{Penutup}

Beragam pemikiran ulama yang telah dikemukakan dalam tulisan ini menggambarkan bahwa problematika fikih perempuan menyisakan ranah ijtihadiyah yang tidak sepi dari ikhtiläf al-'ulama $\vec{a}$. Sementara di sisi lain, produk fatwa ulama senantiasa tidak terlepas dari karateristik manhaj yang dianutnya. Pemikiran fikih klasik hendaklah dikaji ulang secara proporsional dan disegarkan kembali melalui pendekatan-pendekatan yang sesuai dengan kondisi modern. Oleh karena itu, dalam menetapkan hukum fikih perempuan kontemporer, para ulama telah menetapkan 4 metode yaitu:

\footnotetext{
55 M. Quraish Shihab, Perempuan (Cet. VI; Jakarta: Lentera Hati, 2010), 378.

56 M. Quraish Shihab, Perempuan, 385.

57 Majelis Tarjih Pimpinan Pusat Muhammadiyah, Adabul Mar'ah fil Islam (Yogyakarta: Majlis Tarjih PP Muhammadiyah, 1982), 49.

58 Ita Musarrofa, “Analisis Wacana Kritis terhadap Fatwa Bahtsul Masa'il tentang Perempuan”, Ulul Albab, Vol. 18 No. 2 (2017), 145.
} 
analisis komprehensif terhadap nas-nas hukum; atensi terhadap maqāṣid al-syarīah; pertimbangan realitas sosial masyarakat; dan yang terakhir adalah pertimbangan terhadap perbedaan psikologis dan sosial perempuan.

Di Indonesia, kaum perempuan dihadapkan dengan keterbukaan akses informasi, sistem transportasi yang terjamin, dan perkembangan globalisasi sehingga menuntut partisipasi perempuan dalam setiap aspek kehidupan. Jika di beberapa negara Arab akses perempuan terhadap publik masih sangat terbatas, maka realitas di Indonesia mayoritas perempuan diberikan peluang yang sama untuk mengaktualisasikan dirinya baik untuk terlibat dalam pendidikan, ekonomi, bahkan hingga terjun ke politik praktis. Adapun kekhawatiran akan terjadinya kemudaratan bagi perempuan melalui perkembangan realitas tersebut, maka para ulama atau pakar fikih perempuan di Indonesia perlu merespon secara aktif dan memberikan solusi hukum, tanpa bersikap terlalu ketat (tasyaddud) atau terlalu longgar (tahallul).

\section{Daftar Pustaka}

Asni. "Pembaruan Hukum Islam di Indonesia, Telaah Epistemologis Kedudukan Perempuan dalam Hukum Keluarga”. Disertasi. Makassar: PPs UIN Alauddin, 2012.

al-Asyqar, Usamah 'Umar Sulaiman. Manhaj al-Iftā’ 'inda Ibnu Qayyim al-Jauziyyah. Yordania: Dār alNafā'is, 2008.

'Athiyyah, Jamal dan Wahbah al-Zuhaili. Tajdìd al-Fiqh al-Islāmī. Beirut: Dār al-Fikr, 2000.

'Azzām, 'Abdul ‘Azīz Muḥammad. al-Qawā’id al-Fiqhiyyah. Kairo: Dār al-Ḥadīs, 2005.

Fadhilah, Iman. "Aplikasi Hermeneutika dalam Fiqh Perempuan (Studi Pemikiran Khaled Abou el Fadl tentang Fiqh Permepuan dalam Fatwa CRLO)”. Iqtisad, Vol. 3 No. 1 (2016).

al-Hafnāwī, Muhammad Ibrāhim Muhammad. al-Ta'ārud wa al-Tarjịh 'inda al-Ușūliyyīn wa Aśaruhumā fì al-Fiqh al-Islāmī. Cet. II; Mesir: Dār al-Wafā', 1987.

Haid, Faridah. “Al-Iftā' fī Qaḍāyā al-Mar'ah al-Mu'āṣarah baina al-Guluw wa al-I'tidāl”, al-Multaqā alDaulī al-Rābi: Șunā’ah al-Fatwā Fī Zil al-Tahaddiyāt al-Mu'āṣarah, Vol.16 (13-14 Nopember 2019), 155. https://www.univ-eloued.dz/index.php/isi/85-c-institute-science-islamique/tousarticles-ins-islamic/9858-1144701258 (10 Januari 2021).

Hamidah, Tutik. "Dialektika Teks dan Konteks dalam Metode Istinbāṭ Fikih Perempuan Kontemporer". Ahkam. Vol. XIII No. 1 (2013).

Harisudin, M. Noor. "Pemikiran Feminis Muslim Indonesia tentang Fiqh Perempuan”, Al-Tahrir, Vol. 15 No. 2 (2015).

al-Jauziyyah, Ibnu Qayyim. I'lām al-Muwaqqi'în 'an Rabb al-'Ālaminn. Juz 4. Saudi 'Arabiyah: Dār alJauziyyah, 2002.

Lembaga Fatwa Dār al-Iftā’ Mesir. Dawābit al-Ikhtiyār al-Fiqh 'inda al-Nawāzil. Terj. Adhi Maftuhin, Fiqih Nawazil Standar Berfiqih dalam Perbedaan Fatwa. Depok: Keira Publishing, 2017.

Mahmudi, Zaenul. Sosiologis Fikih Perempuan: Formulasi Dialektis Fikih Perempuan dengan Kondisi dalam Pandangan Imam Syafi'i. Cet. I; Malang: UIN Malang Press, 2009

Majelis Tarjih Pimpinan Pusat Muhammadiyah. Adabul Mar'ah fil Islam. Yogyakarta: Majlis Tarjih PP Muhammadiyah, 1982. 
Muhammad, Husein. Fiqh Perempuan Refleksi Kiai atas Tafsir Wacana Agama dan Gender. Cet. I; Yogyakarta: IRCiSoD, 2019.

Musarrofa, Ita. “Analisis Wacana Kritis terhadap Fatwa Bahstul Masa'il Tentang Perempuan”. Ulul Albab, vol. 18 Nomor 2 (2017). http://ejournal.uin-malang.ac.id/index.php/ululalbab/article/ view/4523. (Diakses 21 Maret 2020).

al-Qahtani, Musfir. "Manhaj Istikhrāj al-Aḥkām al-Fiqhiyyah li al-Nawāzil al-Mu'āṣarah”. Juz 1. Saudi Arabiyyah: Kulliyyah al-Syarī’ah wa Dirasāt Islāmiyyah Jāmi’ah Umm al-Qurā, 2000.

al-Qaradawi, Yusuf. Fatāwā al-Mar'ah al-Muslimah. https://www.al-qaradawi.net/sites/default/files/pdf/ da183-FATAWA-ELMAHRAA-ELMOSLIMA.pdf (27 April 2019).

al-Qarāfī, Syihābuddīn Al-Ṣanhājī. Kitāb al-Furūq Anwāru al-Burūq fì Anwā’u al-Burūq. Juz 1. Cet I; Kairo: Dār al-Salām, 2001.

al-Raisuni, Ahmad. Naẓriyyah al-Maqāșid 'inda al-Imām al-Syāțibī. Cet. IV (Herndon USA: The International Institute of Islamic Thought, 1995.

Șālih, Sa'ād Ibrāhim. Aḥkām 'Ibādāt al-Mar'ah fĩ al-Syrī’ah al-Islāmiyyah. Cet. III; Kairo: Dar al-Ḍiyā', 1993. al-Sausah, Abdul Majid Muhammad. Dawābiț al-Fatwā fí Qadāyāal-Mu'āṣarah. https://www.roudabooks. com/book/39440, 225 (23 Februari 2021).

Shihab, M. Quraish. Jilbab, Pakaian Wanita Muslimah, Pandangan Ulama Masa Lalu dan Cendekiawan Kontemporer. Cet.IV; Jakarta: Lentera Hati, 2012.

Shuhufi, Muhammad. Fatwa dan Dinamika Hukum Islam di Indonesia. Makassar: Alauddin University Press, 2011.

Situs Resmi Majelis Fatwa Yordania. http://www.aliftaa.jo. (26 April 2019).

Situs Fatwa Resmi Syekh bin Baz, https://binbaz.org. (27 April 2020).

Situs Fatwa Online Șāid al-Fawā’id. http://www.saaid.net. (10 Februari 2021).

Situs Fatwa Fatwa Center Islamweb. https://www.islamweb.net. (2 Maret 2021).

al-Syātibi, Abū Ishāàq. al-Muwāfaqāt fì Ușūl al-Syarīah. Juz 2. Beirut: Dār al-Kutub al-'Ilmiyyah, 2001.

Tafsir. "Pandangan Muhammadiyah Tentang Perempuan", https://tarjih.or.id/tajdidmuhammadiyah-dalam-persoalan-perempuan/ (10 April 2019).

al-Zuhaili, Wahbah. Fiqh al-Islāmī wa Adillatuh. Juz 7. Cet. II; Suriah: Dār al-Fikr, 1985. 
